\title{
VIEWPOINTS
}

\section{Jurisprudence of Minorities (Fiqh al-Aqaliyyat) Revisited}

\author{
Mohammad Hashim Kamali*
}

In an earlier issue of this journal I introduced the jurisprudence of minorities as being in many ways a new branch of the traditional fiqh that had hitherto remained underdeveloped and is now a work in progress among Muslim scholars and jurists. ${ }^{1}$ The present essay is an extension of that discussion and adds practical illustrations of responses by the Islamic Council of Europe (ICE) to issues facing Muslim minorities in Europe. These are as follows:

\section{Mortgages and Student Loans}

While the Qur'an (2:2765-77) prohibits riba (usury) and warns the violators in a strong language that their wrongdoing is tantamount to waging war against Allah and His Messenger, this very issue presented a practical problem concerning shelter and education to Muslim minority communities in Europe. Islamic banks are not available in many Western countries to make the Islamic alternatives of loans and mortgages available to Muslims. Most Muslim migrants in the West are also not affluent and cannot afford to buy a house without a mortgage. Are they allowed to take interest-based mortgages?

At its fourth session, held on 27-31 October, 1999, the ICE issued a fatwa, endorsed by Yusuf al-Qaradawi, that allowed such mortgages on the basis of necessity (darurah). The Fatwa began with reaffirmation in principle of Islam's prohibition on riba, and encouraged Muslim individuals and institutions to make Islamic banking facilities available in Europe. But until then, a Muslim living in Europe who does not own a house and does not have the means to purchase one without a loan is permitted to take a conventional mortgage. The Council based its fatwa on two grounds: First, that a need (hajah) is elevated to a necessity (darurah) when it affects the community or puts the individual in hardship. A necessity, the fatwa explained, is something without which a Muslim cannot live, and a need is something without which a Muslim would be put into hardship (haraj). The Qur'an (5:6 \& 22: 78) expounds that Islam is not meant to become a means of inflicting hardship on Muslims. Not taking a mortgage under the stated conditions presents a hardship to Muslims that is then elevated to a necessity, and necessity can override a prohibition, based on the Islamic legal maxim that "Necessities make the unlawful lawful (al-darurat tubih al-mahzurat)". 
Second, Islam seeks to strengthen the believers in all respects, including the elimination of financial hardship. When Muslims are unable to own a house in which to live, they will be paying rent to non-Muslim owners all the time, and their inability to select a location that may be closer to a school or mosque, as well as to other Muslims, would mean that their living conditions are negatively affected.

In a study published by the ICE journal in 2009, student loans were also permitted based on reasons that ran parallel to those invoked in relation to mortgages. Salim al-Sheikhi (b. 1964), a Libyan-born, Saudi-educated and England-based jurist and member of the Council argued that because Muslims in Britain do not have access to reliable Islamic-regulated interest-free loans, the principle that a need can be regarded as a necessity can be invoked, which would, in turn, permit the taking of interest-based student loans. The need here is individual as well as communal. For individuals to find good jobs, academic education is required. Because most Muslims in Britain work in low-paid occupations, they are unable to afford higher education if student loans remain prohibited. As for the communal need, unless student loans are made available, the Muslim minority will be harmed, and Islamic law rules that "Harm is neither inflicted nor reciprocated in Islam's [name] - la darar wa la-dirar fi'l-Islam" (hadith-cum-legal maxim). Al-Sheikhi concluded that since the Council has permitted mortgages based on the premise that a need is elevated to necessity, permitting student loans is all the more justified on the same basis.

\section{Service in Western Military Fighting the Muslims}

Shortly after the $9 / 11$ attacks, while the U.S was preparing to attack Afghanistan, a Muslim chaplain in the US Army, Muhammad Abdul Rashid, presented al'Alwani with a query on the permissibility of participation in a war against the perpetrators of the attacks. Al-'Alwani consulted al-Qaradawi, who joined four other jurists in the approval of participation. Their decision was based on two grounds: first, the 9/11 were terrorist acts, and Muslims should be united against those who terrorise innocent people; second, applying fiqh al-muwazanat, they argued that if Muslim American military personnel were to resign their positions they would cause harm not only to themselves but also to millions of Muslim Americans, and this would be a harm greater than that caused by participating in the war. The jurists advised the questioner, however, that he should ask to serve in a non-combat position, unless such a request would raise doubts about his loyalty. In his approval of the participation, al-Qaradawi stipulated in his fatwa that the Muslim soldier must do his best to avoid direct military confrontation. If the soldier has no choice but to participate in war against Muslims, he should 
have an inner feeling of resentment, which is "the least of faith." Refusal to participate may mean, it was added, that "the Muslim [soldier] as well as the Muslim community is accused of high treason," a harm that would far exceed the one incurred by participation.

\section{Remaining Married to a non-Muslim Husband}

In his Fiqh al-Aqaliyyat al-Muslimah, al-Qaradawi discussed the predicament of a female convert married to a non-Muslim and responded to a question as to what she should do: seek divorce, or remain married. ${ }^{2}$ The fatwa was based on selection (takhyir) among scholastic (madhhabi) positions, and on bringing ease (taysir) which Allah wishes for humankind.

The Shariah allows Muslim men to marry Jewish and Christian women, but prohibits Muslim women from marrying non-Muslim men. All the Sunni schools of law have held that if a woman converts to Islam and her husband does not, she must divorce him. That was also the original view of al-Qaradawi, which he revised years later and made it permissible for female converts not to divorce her non-converting husbands. ${ }^{3}$ He wrote that his in-depth study revealed that there was no consensus regarding the obligation of a convert to terminate her marriage with a non-Muslim, adding that the Prophet (pbuh) did not oblige married couples to divorce in cases where only one of them became Muslim, nor did he renew their marital contract. The Prophet allowed women, including his daughter Zaynab, whose husband Ibn al-'As was still a pagan, to wait, even for a long time if necessary, for their husbands to embrace Islam, and then to resume marital relations. Following his example, the caliph 'Umar b. Al-Khattab permitted women who converted to Islam to remain married to their unconverted husband, with expectation of a future conversion.

The ICE initially hesitated in adopting al-Qaradawi's fatwa, which it eventually did. The Council stated that while the four Sunni schools call on female converts to divorce their non-Muslim husbands, some scholars have recorded the view allowing them not to terminate the marriage and to maintain their marital rights and obligations provided their husbands did not restrict them to practice their religion and so long as she aspires to bring him into the fold of Islam. The Council justified this opinion by explaining that women in Europe would otherwise be deterred from embracing Islam. ${ }^{4}$

\section{Inheritance from non-Muslims}

All the leading schools of Islamic law forbid Muslims to inherit from nonMuslims, and for non-Muslims to inherit from Muslims, based on the authority of a clear hadith to that effect. This position has serious implications for the 
financial prospects of Western converts to Islam whose parents did not convert, and also serves as an obstacle to conversion. Al-Qaradawi relying on Ibn Taymiyyah, broke from the consensus. ${ }^{5} \mathrm{He}$ reasoned that Islam seeks to benefit the believers, but the fear that they stand to lose the right to inherit their family's fortune is a major concern of the people who contemplate conversion. Therefore there is a maslahah to permit inheritance from non-Muslims. The ICE adopted this view and explained, as also did al-Qaradawi, that the hadith which forbids inheritance from non-Muslims relates only to non-Muslims who are at war with Muslims (i.e. harbis).

In sum, significant efforts are being made by the ICE and the leading Muslim scholars to allow Muslims in the West greater integration into the majority societies in which they live.

\section{Notes}

* Mohammad Hashim Kamali is the Founding CEO, International Institute of Advanced Islamic Studies (IAIS) Malaysia (Email: ceo@iais.org.my).

1. Muhammad Hashim Kamali and Ahmad Badri Abdullah, "Fiqh Al-Aqalliyāt (Jurisprudence of Minorities) in Light of the Higher Objectives (Maqasid) of Shariah, ICR 6.1 (Jan 2015), 114-117.

2. Yusuf al-Qaradawi, Figh al-Aqaliyyat al-Muslimah (Cairo: Dar al-Shuruq, 2007), 60 .

3. Ibid, $105-6$

4. Cf., Uriya Shavit and iyad Zahalka, "A religious law for Muslims in the West: the European council for Fatwa and research and the evolution of fiqh al-aqaliyyat al-muslima," in Roberto Tertoli, ed., Routledge Handbook of Islam in the West (London and New York: Routledge, 2015), 376.

5. Yusuf A-Qaradwi, 126f. 